\title{
An Adaptive Learning System based on Knowledge Level for English Learning
}

\author{
https://doi.org/10.3991/ijet.v13i12.8004 \\ Sfenrianto Sfenrianto ${ }^{\bowtie}$, Yustinus B. Hartarto, Habibullah Akbar \\ Bina Nusantara University, Jakarta, Indonesia \\ sfenrianto@binus.edu \\ Mukhneri Mukhtar \\ State University of Jakarta, Indonesia \\ Efriadi Efriadi \\ AMIK BSI Jakarta, Indonesia \\ Mochamad Wahyudi \\ STMIK Nusa Mandiri, Jakarta, Indonesia
}

\begin{abstract}
Traditional learning approaches in teaching English assume that learners have same background, ability, and requirements. In this study, we propose an adaptive learning systems-knowledge level (ALS-KL) is a learning system that can personalize materials due to proficiency level of English language learners. A pre-test is given to measure the proficiency level of learners. The level is divided into elementary, intermediate and advanced. The ALS-KL provides the most suitable materials according to the needs of the learners. We applied the proposed system on 90 learners with different English proficiency level. The effectiveness of the system was evaluated using post-test. The results of the posttest showed that the proposed system was able to improve learners with intermediate-level and advanced level 1.5 times and 4 times respectively while reducing the number of learners with elementary-level by more than $50 \%$. These indicate the effectiveness of the proposed system.
\end{abstract}

Keywords-Adaptive Learning, ALS, E-Learning, Knowledge Level

\section{Introduction}

English language learning in general is still conventional. In this conventional model, it does not take notice of the students who have diverse characteristics in terms of background, ability, and requirements. Indeed, unsuitable learning materials in accordance with the characteristics of learners can affect the learning outcomes significantly. This is because basically every individual has different learning requirements. In addition, teachers who have limited time did not allow to make all formats of learning materials that correspond to the characteristics and needs of individual learners. 
On the other hand, the utilization of Information and Communication Technology (ICT) has been widely used to support a more effective learning system. Nowadays, Adaptive Learning Systems (ALS) has been used as an interactive system that can personalize or adapt the learning content according to user requirements [1]. Thus, the system can provide suitable learning materials according to the characteristics of learning styles [2-3], previous knowledge level [4]. The limitation of conventional learning approach can be solved by ALS approach.

In this approach, the different characteristics of student can be mapped and adopted individually for a unique learning experience. The system can provide suitable contents according to learner needs. In other words, each of students do not have to face the same material during the study.

This study proposes an Adaptive Learning Systems-Knowledge Level (ALS-KL). This system identifies the level of knowledge through pre-test. The value pretest will be used determine the level of elementary, intermediate, and then ALS-KL will provide different learning materials based on the knowledge level of students' proficiency in English. This approach is significantly different with the conventional approach.

\section{Related Works}

Adaptive Learning is a learning process in which the material or the content can adapt and change to match the needs of the user [5]. It also providing personalized instruction to students based on their knowledge level [6]. Whereas ALS is required to achieve the necessary adaptive learning [7]. An example of ALS architecture is shown in Figure 1 [8]. This system collects information from user traits, background, preferences and so on. The characteristics of these data will be processed as a profiling of a student model as the basis for personalization or adaptation. The system will update this information periodically during the learning process.

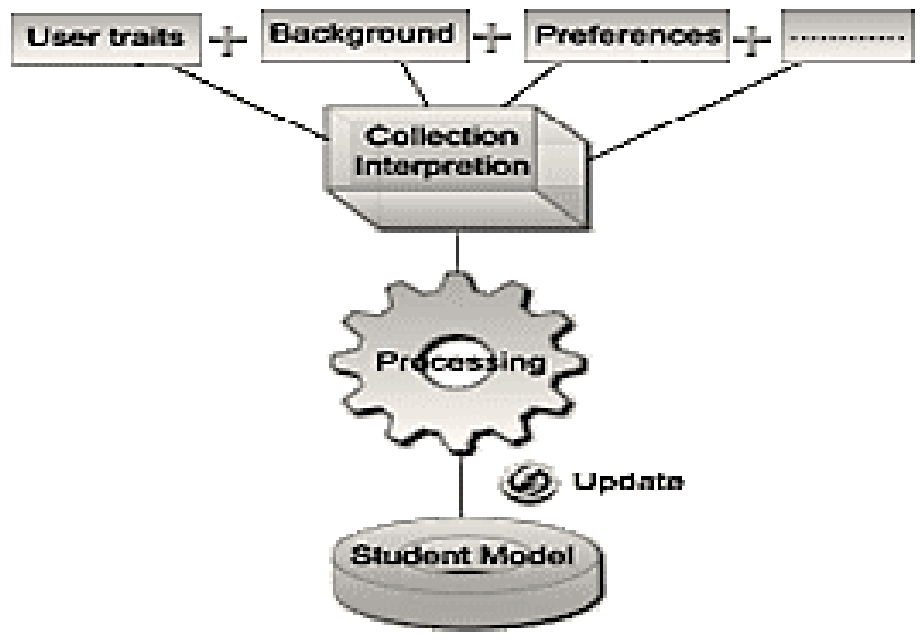

Fig. 1. Adaptive Learning System (ALS) architecture [8] 
Some studies have focused on different aspects of adaptive learning system. For example In Web-based Educational System with Learning Style Adaption (WELSA) for the adaptation of teaching materials of Artificial Intelligence (AI) subjects based on the characteristics of learning styles [9-10]. Adaptive E-learning Hypermedia SystemLearning Style (AEHS-LS) system to adapt teaching materials programming learning PHP based characteristic style [11-12]. Adaptation with Multi-Dimensional Personalization Criteria (AMDPC) system to provide adaptive learning materials of Computer Networking subject based on students' learning styles and cognitive styles [13].

In contrast to the above work, study in [14] have utilized InterBook system to adapt the learning material of database subject based on the characteristics of the knowledge level of the learner. The learning materials can be divided into three levels: novice, average, and excellent [15]. Recently, these levels divide into four categories: fail, sufficient, good, and very good [16].

\section{The Proposed Approach: Adaptive Learning System - Knowledge Level (ALS-KL)}

The ALS-KL system aims to solve the cognitive (knowledge) problems based on the learners' ability. Each participant who use the system to learn English will receive different learning materials according to their own personal proficiency level. To achieve this objective, we developed an adaptive learning system based on the learning level of learners.

The framework of the developed ALS-KL system can be seen in Figure 2. Firstly, the user should register to the system. The use will take a pre-test in order to map the proficiency level. The knowledge levels (elementary, intermediate, and advanced) will be assigned based on the pretest. From the level, the adaptive learning module will personalize the English learning materials. Finally, after a period of time, the user must take a post-test in order to know the effectiveness of learning process.

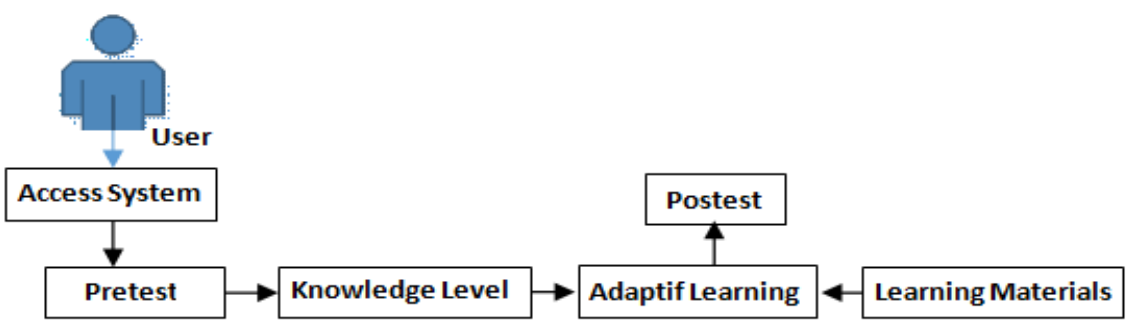

Fig. 2. The Framework of Adaptive Learning System - Knowledge Level

Figure 3 describes the algorithm of the ALS-KL framework. As mentioned before, the process begins with the login process. If the user has not been registered in a study session, the user need to register a new account. Otherwise, the user can directly enter the ID and the password. Then, the process continue with the knowledge-level evaluation. If the user has been assessed previously, then the user will be provided by 
specific learning materials including vocabulary, reading, listening, grammar, and questions according to the English proficiency level. Otherwise, the user must take a pretest to determine the initial proficiency level. The proficiency level is given in Table 1.

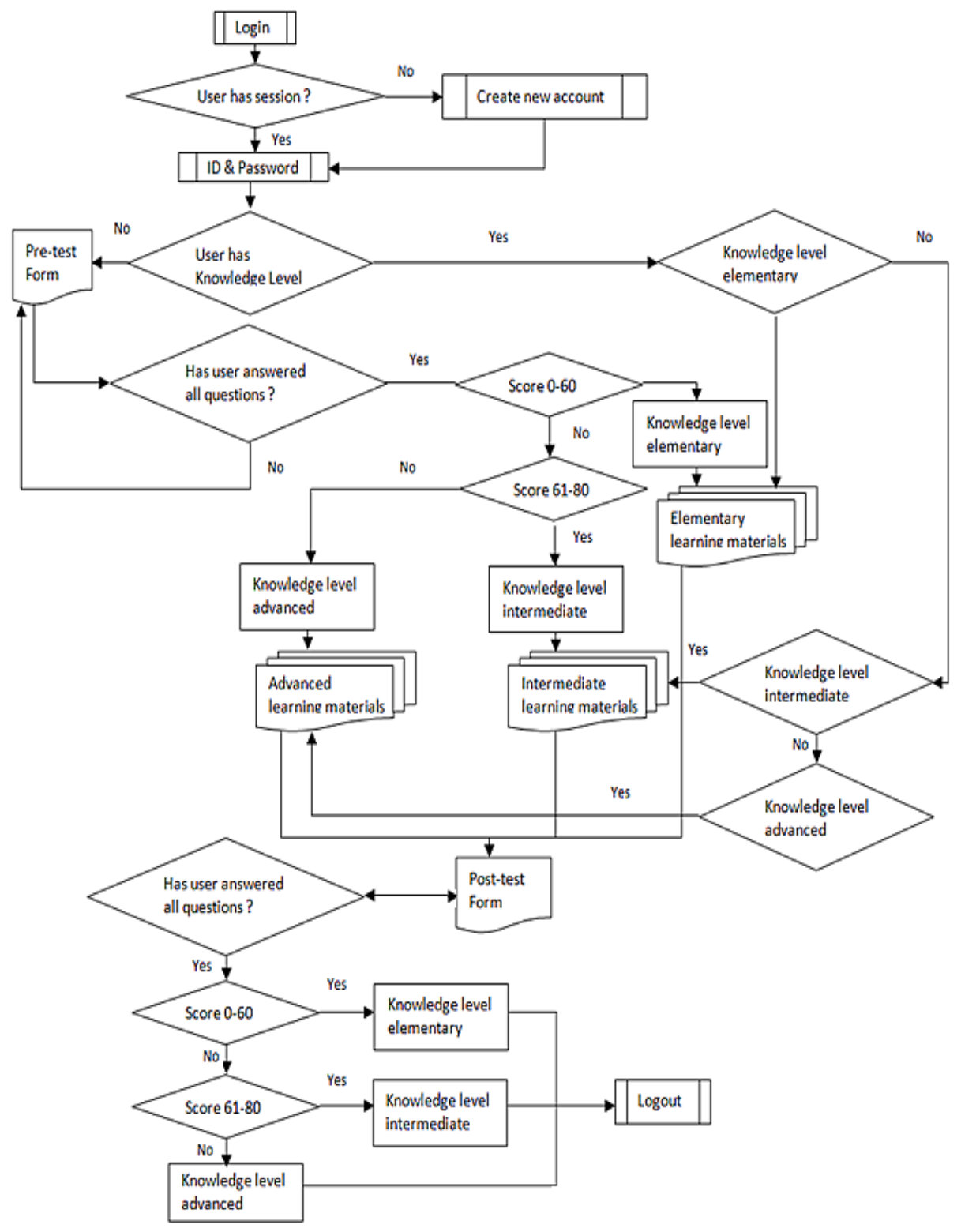

Fig. 3. The Algorithm of Adaptive Learning System - Learning Level 
Table 1. Knowledge level base on pre-test

\begin{tabular}{|l|c|}
\hline Item1 Pre-Test & Knowledge Level \\
\hline $0-60$ & Elementary \\
\hline $61-80$ & Intermediate \\
\hline $81-100$ & Advanced \\
\hline
\end{tabular}

After the learning process, the users will be given a post-test in order to determine the effectiveness of ALS-KL system. The proficiency level of the post-test is determined in the same manner with the pre-test as in table 1 above. After the post-test, this system expects the user can improve from elementary level to intermediate level and from intermediate level to advanced level.

Figure 4, shows an example of the interface how the learners use the ALS-KL system. The other materials including vocabulary, reading, listening and grammar is also presented via this interface. In addition, there is also an evaluation module to test the ability of the participant after each session. After the evaluation, the results of the session will be recorded and updated (see figure 5).

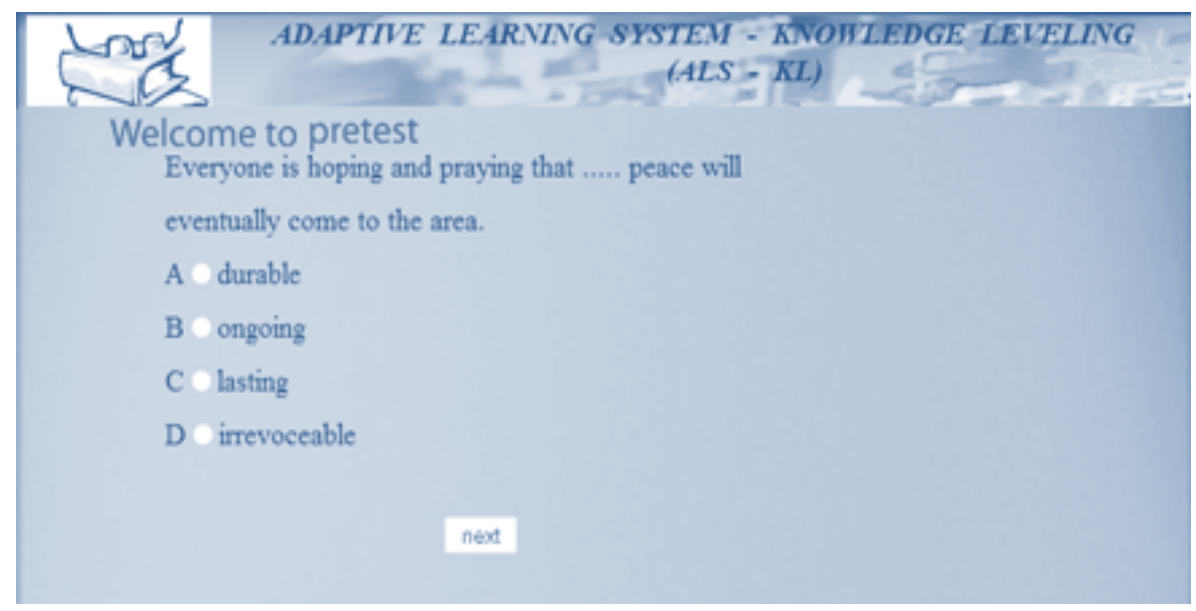

Fig. 4. Pre-test ALS-KL

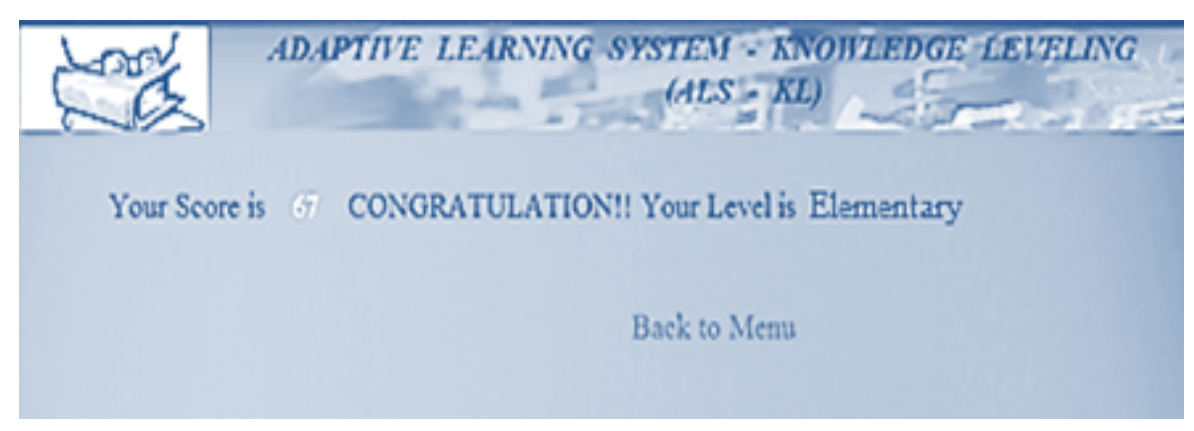

Fig. 5. Knowledge Level ALS-KL 


\section{Effectiveness of ALS-KL System}

In order to test the effectiveness of ALS-KL, we test the system on 90 learners, consisting of categories of age $\leq 20$ years as many as 17 people (14\%). For age $21-30$ years, there are 76 people $(63 \%)$. For the category of $31-40$ years, there are 27 people $(24 \%)$.

In this study, the students learn English language through the Adaptive Learning System - Knowledge Level (ALS-KL). Adaptive learning system is given to each learner through the user interface that can be accessed by a computer/laptop. The learning activities are completed in 1 month, which is given twice a week. Tables 2, 3, and 4 are the design of learning materials for each knowledge level. After the learning process, the user will be given a post-test to see knowledge update after learning process.

Table 2. Elementary learning materials

\begin{tabular}{|c|l|l|l|l|}
\hline Day & \multicolumn{1}{|c|}{ Listening } & \multicolumn{1}{|c|}{ Grammar } & \multicolumn{1}{c|}{ Reading } & \multicolumn{1}{c|}{ Writing } \\
\hline Day1 & College Life & Present simple & $\begin{array}{l}\text { Let me introduce my- } \\
\text { self }\end{array}$ & Applying for a job \\
\hline Day2 & Meetings Singles & $\begin{array}{l}\text { Comparatives and superla- } \\
\text { tives }\end{array}$ & The Dead Pedestrian & $\begin{array}{l}\text { Give arguments for or } \\
\text { against teenage working }\end{array}$ \\
\hline Day3 & Picnic Preparation & common uncountable nouns & Influenza & My dream job \\
\hline Day4 & Reading Time & Past simple of "to be" & $\begin{array}{l}\text { Freeway Chase Ends } \\
\text { at Newsstand }\end{array}$ & My dream school \\
\hline Day5 & Train Tickets & $\begin{array}{l}\text { Prepositions of time, includ- } \\
\text { ing in/on/at }\end{array}$ & The Pet Chicken & My favorite subject \\
\hline Day6 & Airport Arrival & Past simple of "to" & Back to Schools & $\begin{array}{l}\text { Problems of young } \\
\text { People }\end{array}$ \\
\hline Day7 & Meeting the Guys & School uniforms & Taking the Bus & $\begin{array}{l}\text { What I think about } \\
\text { Fashion }\end{array}$ \\
\hline Day8 & Clothing Styles & Adverbs of frequency & Taking the Bus & $\begin{array}{l}\text { What I think about } \\
\text { Fashion }\end{array}$ \\
\hline
\end{tabular}

Table 3. Intermediate learning materials

\begin{tabular}{|c|l|l|l|l|}
\hline Day & \multicolumn{1}{|c|}{ Listening } & \multicolumn{1}{|c|}{ Grammar } & \multicolumn{1}{c|}{ Reading } & \multicolumn{1}{c|}{ Writing } \\
\hline Day1 & $\begin{array}{l}\text { A Story to Re- } \\
\text { member }\end{array}$ & Adjectives - comparative & $\begin{array}{l}\text { Man Injured at Fast } \\
\text { Food Place }\end{array}$ & My hobbies and interests \\
\hline Day2 & College Major & Adjectives - superlative & $\begin{array}{l}\text { Fishing Boat Sinks, } \\
\text { Everyone Saved }\end{array}$ & My favorite pop group \\
\hline Day3 & Health Activities & $\begin{array}{l}\text { Articles - with countable and } \\
\text { uncountable nouns }\end{array}$ & Goats Being Hired & My favorite sport \\
\hline Day4 & Holiday Tradition & Modals - should & Eggs and a Bunny & An interesting weekend \\
\hline Day5 & Medical Advice & Prepositional phrases & $\begin{array}{l}\text { Pilot Killed in Plane } \\
\text { Crashes into House }\end{array}$ & An interesting film/book \\
\hline Day6 & Cyberbullying & Present continuous for future & $\begin{array}{l}\text { Valuable Guitar } \\
\text { Found }\end{array}$ & $\begin{array}{l}\text { Plans for my next holi- } \\
\text { days }\end{array}$ \\
\hline Day7 & Career Search & Adverbs of frequency & A Festival of Books & $\begin{array}{l}\text { I have a dangerous } \\
\text { hobby }\end{array}$ \\
\hline Day8 & $\begin{array}{l}\text { Computer Sales } \\
\text { and Repairs }\end{array}$ & Gerunds & Pizza Delivery & My dream school \\
\hline
\end{tabular}


Table 4. Advanced learning materials

\begin{tabular}{|c|l|l|l|l|}
\hline Day & \multicolumn{1}{|c|}{ Listening } & \multicolumn{1}{|c|}{ Grammar } & \multicolumn{1}{c|}{ Reading } & \multicolumn{1}{c|}{ Writing } \\
\hline Day1 & Cancer Treatment & Future continuous & $\begin{array}{l}\text { The Park That Went } \\
\text { to the Dogs }\end{array}$ & My dream school \\
\hline Day2 & Enjoying the Zoo & Present perfect/past simple & Eat Your Vegetables & My hobbies and interests \\
\hline Day3 & Flower Shop & Simple passive & A Life-Saving Cow & My favorite pop group \\
\hline Day4 & $\begin{array}{l}\text { Alcoholics Anon- } \\
\text { ymous }\end{array}$ & Both, either, neither & Cloning Pets & My favorite sport \\
\hline Day5 & Drug Addiction & Prepositions of place & New Shoes & An interesting weekend \\
\hline Day6 & Divorce Lawyers & $\begin{array}{l}\text { Comparatives and superla- } \\
\text { tives }\end{array}$ & Learning to Ride & My favorite sports \\
\hline Day7 & $\begin{array}{l}\text { A University De- } \\
\text { gree }\end{array}$ & Simple passive & Life in Fear & I like fast food \\
\hline Day8 & University Degree & Embedded questions & Addicted to Coffee & I'm a vegetarian \\
\hline
\end{tabular}

Figure 6 shows the percentage of the knowledge level of the users after following the pretest. From 90 users, 58\% (52 learners) at the elementary level, 37\% (33 learners) at the intermediate level, and 5\% (5 learners) at the advanced level.

After following the pre-test, each of the 90 learners were given training material that consists of various modules such as vocabulary, listening, grammar and reading in accordance with the level of knowledge acquired. After the session, the learners are given a post-test to determine the extent to which the learners' ability to understand the materials. The results can be seen in Figure 7.

From 90 users, 22\% (20 learners at the elementary level), 56\% (50 learners in intermediate level), and 22\% (20 learners at the advanced level). From this posttest evaluation, it can be seen, that the proposed system was able to improve the proficiency of the learners compared to the pre-test results.

Figure 8 shows the difference between proficiency level between the pre-test and post-test. The elementary level was decrease from $58 \%$ in pre-test to $22 \%$ on the post-test. For the intermediate level, there was an improvement from $37 \%$ to $56 \%$. For advance knowledge level, there is also an increment from $5 \%$ to $22 \%$.

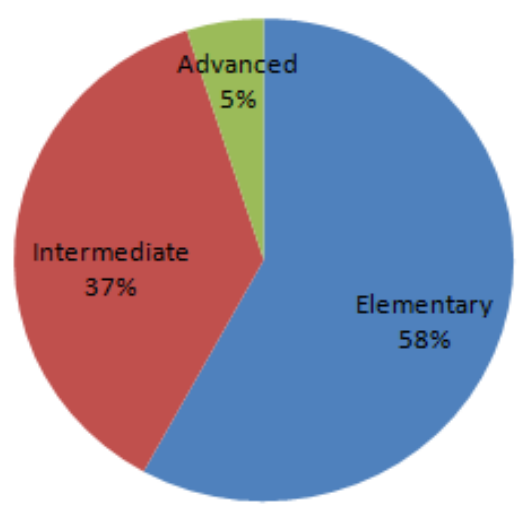

Fig. 6. The results of the pre-test 


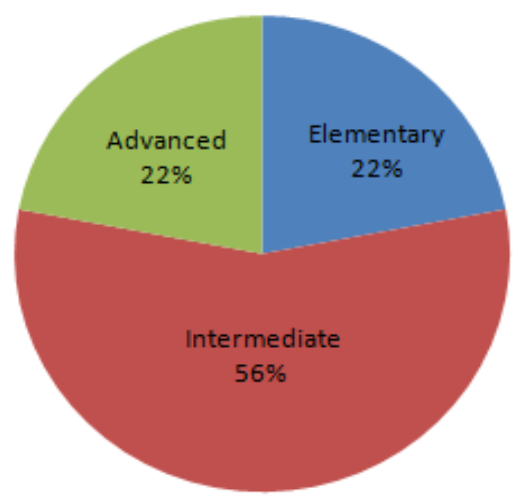

Fig. 7. The results of the Post-test

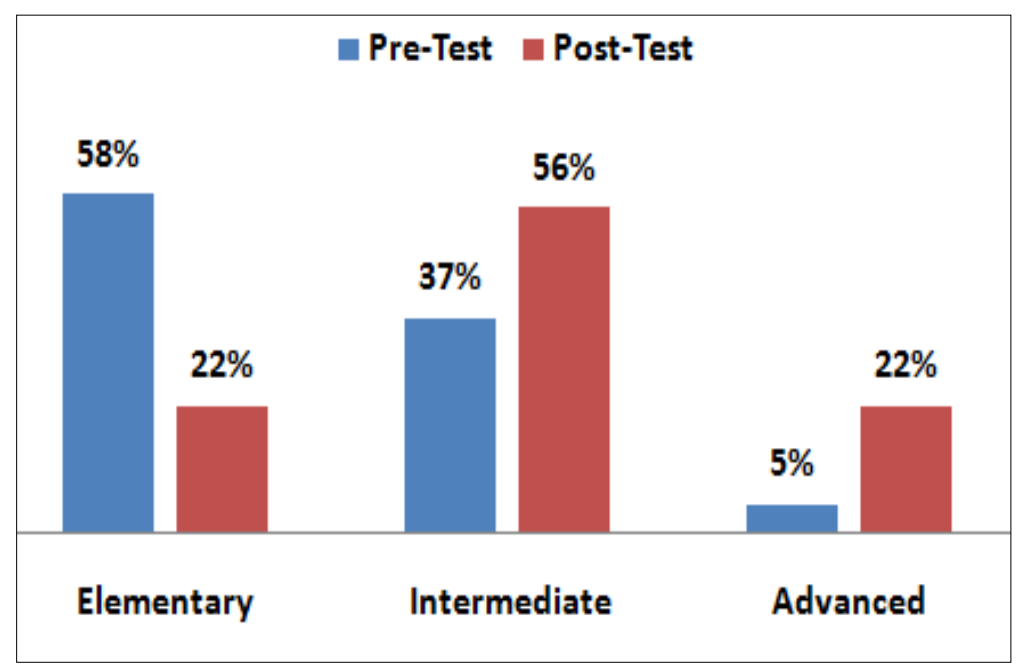

Fig. 8. Comparison of proficiency level between the pre-test and post-test

The effectiveness of ALS-KK can also be seen from the average value of each proficiency level in the pre-test and post-test, (see Figure 9). Value - average students who were in the previous elementary level 57 while following the pre-test to 72 after following a post-test. In the elementary level, the average value of students who previously 67 to 75 after following the post-test. Likewise, the advanced level has increased from the previously 80 to 85 after following a post-test. 


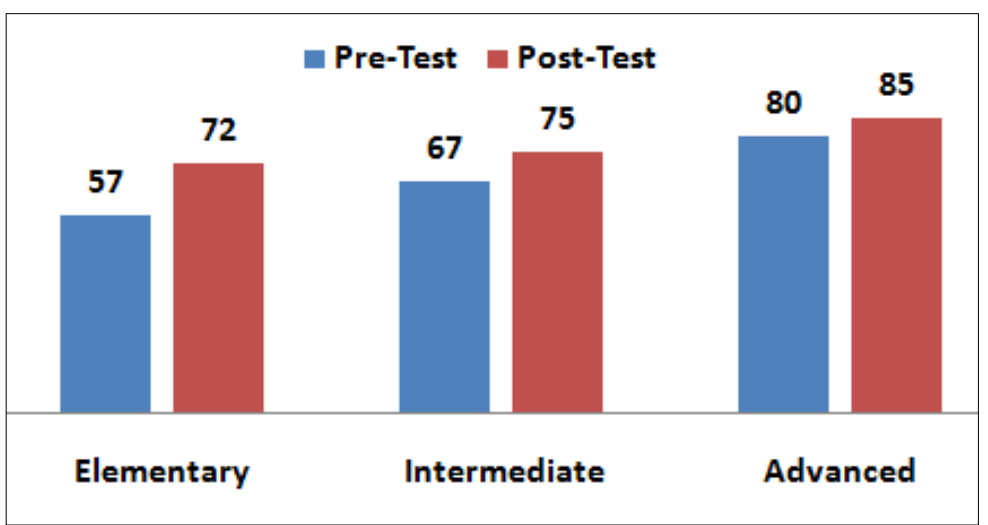

Fig. 9. Comparison of the proficiency level after the post-test

\section{Conclusion}

This study has proposed an adaptive learning system - knowledge level (ALS_KL) for learning of the English language. The system can provide different learning materials according to the proficiency level of the learner. The proposed system has been evaluated on 90 users. We have found that the system was able to improve the English proficiency of the user significantly. This indicates that adaptive learning system is more suitable for learning English. In future works, we expect further experiments that can compare the adaptive learning system with other types of learning approaches.

\section{References}

[1] Judy C.R.T., Hui-Chun C, Gwo-Jen H, Chin-Chung T. (2008). Development of an adaptive learning system with two sources of personalization information. Computers \& Education, 51(2), 776-786. https://doi.org/10.1016/j.compedu.2007.08.002

[2] Siadaty, M., Taghiyareh, F. (2007). PALS2: Pedagogically adaptive learning system based on learning styles. In Seventh IEEE International Conference on Advanced Learning Technologies (ICALT), pp. 616-618). https://doi.org/10.1109/ICALT.2007.198

[3] Chen, S., Zhang, J. (2008) The adaptive learning system based on learning style and cognitive state. In Knowledge Acquisition and Modelling (KAM). International Symposium, pp. 302-306. https://doi.org/10.1109/KAM.2008.60

[4] Hämäläinen, W. (2005). General paradigms for implementing adaptive learning systems. In Proceedings of IADIS Virtual Multi Conference on Computer Science and Information Systems (MCCSIS).

[5] Thalmann, S. (2014). Adaptation criteria for the personalised delivery of learning materials: A multi-stage empirical investigation. Australasian Journal of Educational Technology, 30(1), pp. 45-60. https://doi.org/10.14742/ajet.235

[6] Chaplot, D.S., Rhim, E., Kim, J. (2016) Personalized adaptive learning using neural networks. In: Proceedings of 3rd ACM Conference on Learning @ Scale. pp.165-168. https://doi.org/10.1145/2876034.2893397

[7] Battou, A., Zohr, I., El Mezouary A., Mammass, D. (2011). Towards an Adaptive Learning System Based on a New Learning Object Granularity Approach. International Journal of 
Advanced Computer Science and Applications. vol. 2 (9), pp 8-14. https://doi.org/10.14569/IJACSA.2011.020902

[8] Somyürek, S. (2009). Student modeling: Recognizing the individual needs of users in elearning environments. International Journal of Human Sciences, vol.6 (2), pp. 429-450.

[9] Popescu, E., Badica, C., Moraret, L. (2010). Accommodating learning styles in an adaptive educational system. Informatica, 34(4), pp. 451-462.

[10] Popescu, E., Bădică, C., \& Moraret, L. (2009). WELSA: An intelligent and adaptive Webbased educational system. In Proceedings of the 3rd symposium on intelligent distributed computing (pp. 175-185). https://doi.org/10.1007/978-3-642-03214-1 17

[11] Mustafa, Y. E. A., Sharif, S. M. (2011). An approach to adaptive e-learning hypermedia system based on learning styles (AEHS-LS): Implementation and evaluation. International Journal of Library and Information Science, 3(1), 15-28

[12] Tsortanidou, X., Karagiannidis, C. Koumpis, A. (2017). Adaptive Educational Hypermedia Systems based on Learning Styles: The Case of Adaptation Rules.Vol 12 (05), pp. 150-16. https://doi.org/10.3991/ijet.v12i05.6967

[13] Yang, T. C., Hwang, G. J., Yang, S. J. H. (2013). Development of an Adaptive Learning System with Multiple Perspectives based on Students? Learning Styles and Cognitive Styles. Educational Technology \& Society, 16(4), 185-200

[14] Brusilovsky, P., Karagiannidis, C., Sampson, D. (2004). Layered evaluation of adaptive learning systems. International Journal of Continuing Engineering Education and Life Long Learning, 14(4-5), 402-421.

[15] Giridharan, A. (2005). Adaptive e-Learning environment for students with divergent knowledge levels. e-Learning and e-Learning Technologies (ELELTECH 05).

[16] Sfenrianto, Hasibuan, Z. A., Suhartanto, H., \& Selviandro, N. (2014). An Approach to Detect Learning Types Based on Triple-Factor In e-Learning Process. Journal of Next Generation Information Technology, 5(1), 9.

\section{$7 \quad$ Authors}

Sfenrianto is a faculty member of the Information Systems Management Department, BINUS Graduate Program - Master of Information Systems Management, Bina Nusantara University, Jakarta 11480, Indonesia. (e-mail: sfenrianto@binus.edu).

Yustinus B. Hartarto is a student of the Information Systems Management Department, BINUS Graduate Program - Master of Information Systems Management, Bina Nusantara University, Jakarta 11480, Indonesia. (e-mail: hartarto@gmail.com).

Habibullah Akbar is a faculty member of the Computer Science Department, BINUS Graduate Program - Master in Computer Science, Bina Nusantara University, Jakarta 11480, Indonesia. (e-mail: habibullah.akbar@binus.ac.id).

Mukhneri Mukhtar is a Lecturer of State University of Jakarta, Indonesia. (e-mail: mukhneri@unj.ac.id).

Efriadi is a Lecturer of AMIK BSI Jakarta 11480, Indonesia. (e-mail: efriadi@bsi.ac.id).

Mochamad Wahyudi is a Lecturer of STMIK Nusa Mandiri, Indonesia. (e-mail: wahyudi@nusamandiri.ac.id).

Article submitted 19 November 2017. Resubmitted 13 August 2018. Final acceptance 15 August 2018. Final version published as submitted by the authors. 